Relations industrielles

Industrial Relations

\title{
Kenneth A. MERCHANT : Control in Business Organization. Boston, Pitman, 1985, 161 pp., ISBN 0-273-01914-7
}

\section{Alexander J. Matejko}

Volume 40, numéro 3, 1985

URI : https://id.erudit.org/iderudit/050175ar

DOI : https://doi.org/10.7202/050175ar

Aller au sommaire du numéro

Éditeur(s)

Département des relations industrielles de l'Université Laval

ISSN

0034-379X (imprimé)

1703-8138 (numérique)

Découvrir la revue

Citer ce compte rendu

Matejko, A. J. (1985). Compte rendu de [Kenneth A. MERCHANT : Control in Business Organization. Boston, Pitman, 1985, 161 pp., ISBN 0-273-01914-7]. Relations industrielles / Industrial Relations, 40(3), 685-686.

https://doi.org/10.7202/050175ar

Tous droits réservés @ Département des relations industrielles de l'Université Laval, 1985
Ce document est protégé par la loi sur le droit d'auteur. L'utilisation des services d'Érudit (y compris la reproduction) est assujettie à sa politique d'utilisation que vous pouvez consulter en ligne.

https://apropos.erudit.org/fr/usagers/politique-dutilisation/ 
Par la suite, Munemichi Inoue expose le rôle de la concurrence et de la coopération entre les compagnies dans la croissance économique rapide du Japon ou comment les Japonais ont su contourner leurs faiblesses en formant des groupes industriels forts pour pallier aux déficiences des entreprises individuelles et améliorer leurs méthodes de gestion et la qualité de leurs produits.

La politique industrielle du Japon est ensuite le sujet abordé par Toshimasa Tsuruta. Il s'attache à détruire le mythe d'un système économique japonais spécial dans lequel le gouvernement serait la locomotive du développement économique. Selon lui, même si les politiques gouvernementales protectionnistes ont aidé à structurer solidement l'économie japonaise, certains secteurs industriels, comme celui de l'automobile, ont su refuser cette aide et ne se fier que sur leurs propres ressources et ont quand même obtenu le succès que l'on connaît. Le rôle moteur du gouvernement est donc loin d'être une réalité.

Au dixième chapitre, Saburo Okita traite de la planification économique. L'entreprise privée étant à la base de l'économie japonaise, celle-ci n'est donc pas une économie planifiée, même si le gouvernement procède à une certaine planification par le biais de son agence de planification. Les plans adoptés n'ont qu'une valeur incitative et servent principalement à orienter de façon globale les entreprises. L'importance d'une bonne planification sera cependant déterminante pour que le Japon entre dans le vingt-et-unième siècle sur le bon pied.

Enfin Hisao Kanamori dresse un bilan de l'économie japonaise actuelle et fait des prospectives pour le futur. En se basant sur l'évolution de l'économie depuis le début de la décennie de 1960 , il conclut en affirmant son optimisme.

Hélène BOIS-BROCHU

\section{Université Laval}

Control in Business Organizations, by Kenneth A. Merchant, Boston, Pitman, 1985, xii - 161 pp., ISBN 0-273-01914-7

In order to ensure the proper behaviour of people in organizations it is possible to focus either on results, or on actions, or on personnel. In the first case a good knowledge is necessary as to what results are actually desirable (in bureaucracy this is quite often much confused), these results have to be controllable, and the measures of performance have to be precise enough. "The measures used are good only to the extent that they accurately reflect the organization's true objectives, or at least are consistent with the strategy that has been established) (p. 25). In the case of action controls behaviour of people may be constrained more or less effectively, preaction reviews (rehearsals) are practiced, people are kept accountable for their actions, and additional personnel is allocated to make sure that the duties will be definitely fulfilled. In the case of personnel controls individuals may be adequately indoctrinated and group pressures may be applied.

There is a wide choice of control alternatives and the feasibility considerations are needed in order to make an adequate choice. Controls may be tighter or looser depending on their relative cost and efficiency. The optimal variant is to have a tight control without pushing people much and damaging their personal freedom. The negative side effects have to be kept to minimum: the behaviours encouraged by the control may be inconsistent with the organization's objectives, action controls may be displaced, there may be a gamesmanship on the side of managers producing spurious effects, operating delays may result from controls, negative attitudes may appear among the personnel, financial accountability controls may be not appropriately designed. 
Good understanding of roles being controlled and the key actions that must be performed in order to provide the highest probability of success is crucial in order to design a successful control system. Multiple forms of control reinforce each other and provide the best chance to succeed. On the other hand, control may become a goal in itself defeating the dominant purpose of a given organization.

It does not make much sense to sacrifice effectiveness for the purpose to have a tight control of everything that happens in an organization. Decentralization of decisions and the delegation of power to lower levels make sense even if control seems to weaken. The appearance of order should not be confused with the actual functioning of a given order. Free people are not necessarily chaotic; spontaneity may provide more than formalization; pluralism may be better productive than centralism.

Alexander J. MATEJKO

University of Alberta

\section{LES RÉGIMES DE RETRAITE}

Préface, Rodrigue BLOUIN - Introduction: Jean-Paul DESCHENES, Gilles FERLAND, Jacques ST-LAURENT, Jean SEXTON - La retraite: votre problème!, Bernard SOLASSE - Des solutions aux problèmes de la retraite, Michel BENOIT - Les principaux régimes de retraite et leur contenu, Jacques FAILLE - Les aspects économiques de la réforme des pensions, Gérard BÉLANGER Commentaire: Raymond DEPATIE - Table ronde: La protection du revenu à la retraite: une responsabilité partagée?, Claire BONENFANT, Yves GUÉRARD, Réal LAFONTAINE, Martial LAROEST - Table ronde: Qui doit administrer les régimes de retraite: l'employeur ou le syndicat?, Hervé HEBERT, Jacques PERRON, Lise POULIN-SIMON - Les politiques gouvernementales en matière de retraite, Monique BEGIN - Les politiques gouvernementales en matière de retraite, Jacques PARIZEAU - Réflexions sur les problèmes de la retraite dans les années 80 , John Kenneth GALBRAITH - Commentaire: Maurice LAMONTAGNE.

ISBN 2-7637-6992-6

1 volume, 276 pages - 1982 - Prix: $\$ 17.00$

Les Presses de l'Université Laval

Cité universitaire

C.P. 2447, Québec, P.Q., Canada, G1K 7R4 